\title{
Cognitive, Emotional Intelligence and Social Development of Adolescents of Asasipintar in Accordance to the Internet Advancement
}

\author{
Tengku Elmi Azlina Binti Tengku Muda, Nor Ashika Binti Nasirudeen*, Rorlinda Binti Yusof, \\ Mohd Affendi@Ewan Bin Mohd Matore, Nurulhaidah Binti Daud
}

\begin{abstract}
Internet as a common technology in the current life of humans enhances the quality of human lifestyles including adolescents who are teenagers from 12 to 18 years old. Cognitive development of the adolescents is said to be their brain processing method which is also indirectly related to their neurological and intellectual development whereas emotional intelligence of adolescents is the maturation in the behaviour of an adolescent and social development of the adolescents described as the interaction skills of the adolescents. Therefore, the major aim of this research is to determine the relationships between the cognitive, emotional intelligence and social development of the adolescents in. accordance to the rapid development of technology known as the Internet. In this research, the Working Memory Test (WMT) together with Trait Emotional Intelligence Questionnaire- Short Form (TEIQueSF) as well as the Social Self-Efficacy Scale (SSE) and Internet Addiction Test (IAT) to determine the correlation between the cognitive, emotional intelligence and social development of adolescents of ASASIpintar in accordance to the Internet advancement. The sample was 130 students of ASASIpintar, University Kebangsaan Malaysia. Research finding showed that there is a significant relationship between the cognitive, emotional intelligence and social development of the adolescents in accordance to the Internet advancement.
\end{abstract}

Keywords: Cognitive, Emotional Intelligence, Social, Internet, Adolescents, ASASIpintar.

\section{INTRODUCTION}

Adolescence is the stage of transformation of a child into an adult through a series of internal and external changes mentally and physically to achieve growth and maturity which ranges from the age of 12 to 18 years old (Peterson, 2004). Adolescents are referred to those who are in between the stage of a child and an adult. This is a very crucial phase whereby an adolescent has to decide who is he going to be in the future. Besides, during this adolescence stage, the teenagers are emotionally separated from their parents and

Revised Manuscript Received on November 11, 2019.

* Correspondence Author

Dr Tengku Elmi Azlina binti Tengku Muda, Counselor and senior lecturer at Genius@Pintar National Gifted Centre, UKM

Nor Ashika binti Nasirudeen, Faculty of Medicine

PM Dr Rorlinda Yusof is Deputy Director and senior lecture at GENIUS@Pintar Negara Universiti Kebangsaan Malaysia.

Dr. Mohd Effendi @ Ewan Mohd Matore (PhD), Assistant Dean (Quality Assurance and Strategy) and senior lecturer at Faculty of Education, Universiti Kebangsaan Malaysia (UKM).

Dr Nurulhaidah Daud is a Senior Lecturer at GENIUS@Pintar Nationa Gifted Centre, UKM certain adjustments are mend to be made in themselves in order to face the challenges along the transition period. At the same time, more personal values are instilled in oneself. However, it is in their hands to choose whether the values are to be good or bad. As we know, not many teenagers succeed in determining the right pathway when they enter the new phase of life and some are unfortunately misled by the influences around them. Furthermore, this is the time when a teenager would search for his clear yet specific role in his own society (Christie \&Viner, (2005) but most of the times, ends up being occupied by an ambiguous period between the childhood and adulthood. According to certain specialists, the predicaments throughout the adolescence is often exaggerated since for a mass number of adolescents, this process of maturation is more likely to be smooth and peaceful with less trouble, Nevertheless, there is also a quite number of specialists who describes adolescence as an intense and difficult phase which is accompanied by stressful developments caused by certain behavioural changes. Generally, adolescents are known to be rebellious, thoughtless, distracted and daring. This is mostly because they undergo intense hormonal changes (Ramalingam, (2004) which makes it hard for them to know how to behave. This situation could be managed if and only if the elders play their pivotal roles in guiding the younger generation (Kagu, (2000) based on their experience, so that they do not get dragged into the darker side of the world.

As mentioned earlier, the character of an adolescent is moulded based on many factors influencing them. First of all, it would definitely be the people around them such as parents, friends and followed by their regular activities. Having said about regular activities, it is definitely noticeable that adolescents nowadays are very much distracted and addicted to the $21^{\text {st }}$ century's modern inventions known as the technology (Markey \& Wells ( 2002); Bayraktar \& Gün, (2007). To be more specific, it could be said as the Internet. According to Wikipedia, Internet could be defined as a global system of interconnected computer networks that use the Internet protocol suite (TCP/IP) to link devices worldwide. It is a network of networks that consists of private, public, academic, business, and government networks of local to global scope, linked by a broad array of electronic, wireless, and optical networking technologies with extravagant amount of information. The usage of this source of information is widely spread among the adolescent in this global era for education via educational websites such 
as TED.com, Khan Academy and Compass Learning and to obtain creditable information there is always sources like Wikipedia. Internet as a popular interpersonal communication (Quigley \& Blashki, 2003), they could. access the social medias such as Facebook (Chubb, 2010), Twitter and Instagram as well as for information sharing, mediums such as Gmail and Yahoo. Moreover, Internet is also prevalent among the adolescents as a channel to unwind themselves from the daily grinds through online video gaming (Roberts et al, 2004). The diversity usage of the Internet has definitely attracted the minds of the growing adolescents to spend most of their time by gawking at the electronic screens. A study by Nie Erbring (2000) concluded that women were more exposed to severe addiction to internet, therefore they had more problems in using internet than men and this had led to more urge in the study of the cognitive, emotional intelligence and social development of adolescents in accordance to the Internet usage.

Hours of utilizing the Internet technology by the adolescents has provided significant changes in the various development and revolution of their characters, especially during the process of mental and physical maturation. The impact of the Internet on the adolescents can be divided into several categories such as the cognitive, emotional and social development. First and foremost, cognitive development is closely related to the brain development in which addiction can affect one's memory and learning (Robinson and friends, 2004) and specific neurological structures (Das \& Naglieri, 2001). Besides, the cognitive development of an adolescent can be interpreted as the information processing, conceptual resources, perceptual skill, language learning (Solso et al, 2005), and other aspects of the developed adult brain and cognitive psychology. This is known as the study of mental processes such as attention, language use, memory (Sweller et al., 1998), perception (Bandura, 1978), problem solving (Luria, 1973), creativity, and thinking. It is also can be said as how an adolescent understands and articulates a subject consciously. At times, cognitive development of an adolescent is referred as to their intellectual development which is closely related to their academic performance and how they perceive the world around them. It also results in more progressive individuals who are able to function effectively in the surrounding environments (Luria, 1976). This cognitive development is believed to be affected by the Internet advancement.

The cognitive development of adolescents is also closely related to their emotional intelligence since their way of interpretation and perception determine the components of their emotional intelligence. Emotions is known as the strong feelings of one resulting from his situations and mood as well as their relationships with the others. In the context of adolescents' emotional development, it is stated that an adolescent's emotion is constantly fluctuating in order to achieve emotional maturity as he come to know his true unique identity. Here comes emotional intelligence (EQ) which could be defined the capability of a person to manage and control his or her emotions and possess the ability to control the emotions of others (Goleman, 1996, 2004; Mayer et.al, 2000; Salovey \& Mayer,1990) as well. It is said to have five main elements such as - self-awareness, self-management, social awareness and relationship management (Segal, 2008). Emotional intelligence also includes both internal and external elements. Subsequently, the concept of emotional intelligence is a multifactor domain of a set of social skills and competencies that affects one's ability to recognize emotional understanding and management, problem solving, and adaptation, and effectively adapt the person to the needs and pressures and challenges of life (Parker et al.2008). Similarly, Salovey and Mayer (1990) think that emotional intelligence involves the ability to monitor one's own and others' feelings and emotions, to discriminate among them and to use this information to guide one's thinking and actions. In addition to that, some believe that emotion management skills involve verbal and spontaneous expression of emotions, the ability to manage emotions and control negative physical reactions, coping and anger management (Cecen, 2006). During the adolescence phase, the teenagers experience extreme feelings and great emotions at different circumstances whereby their moods are barely predictable. This eventually results in various internal and external conflicts in an adolescent such as parent-youth conflict (Subrahmanyam \& Greenfield, 2008; Mesch, 2006) as he learns to deal and express his emotions in a more grown-up way. On the other hand, they also become more sensitive of words and expression of the others towards them. Besides, they become more self-conscious regarding their physical appearance and changes. Their self- esteem or confidence is often related to their appearance on how they look. They tend to compare their physical bodies with their friends and peers to obtain the perfect image of themselves in another people's perspective. It is also found that due to changes in emotional development during adolescence, they experience changes in the relationship, they prefer to spend more time with friends than family (Lee, 2009) and tend to develop arguments with their parents on trivial matters as they seek more independence. As they are maturing, they begin to think more abstractly and question different point of views. Coming back to the topic, emotional development has a significant relationship with the Internet advancement when it is used as a medium by a teenager to express himself as well as involve in activities such as risk-tasking behaviours, faulty socialization and loneliness (Beebe et.al. 2004); Markey \&Wells (2002); Mesch (2001). To compare between the level of emotional intelligence between boys and girls in terms of general EI, some studies find that women have better self-perception (Saklofske, Aus-tin, \& Minski, 2003); Van Rooy, Alonso, \& Viswesvaran,( 2005), while others maintain that this is the case for men (Kong et.al, 2012); Mikolajczak et.al (2007); Shi \& Wang, 2007).

The following is the social development of the adolescents which is affected by the usage of Internet. The adolescents' social developments involve the dramatic change in their quantity and quality of social relationships. As their emotions and thoughts become complex during adolescence, their social relationships also tend to become more complex. Their social sphere which has been previously occupied only by their friends and family, expands greatly into a more intrinsic network including many more people and many types of different relationships.

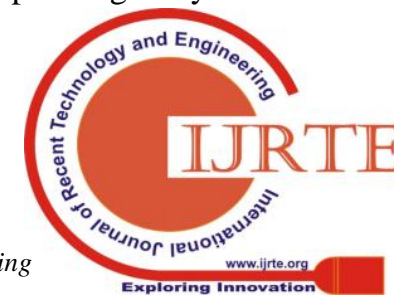


Furthermore, the social changes occur continuously as they search for their identities, seek for more independence and responsibilities. They also look for new experiences as their nature of brain development induces them to be more engaged in risk-tasking behaviour as they develop control over their impulses. The adolescents commence to think about the right and wrong in the social community and develop morals and values. They also learn that they are responsible for their own actions, decisions and consequences. Besides, some intends to develop sexual identity whereby they start to have sexual and romantic relationships (Wolak et.al 2003) as well as according to certain resources boys are more vulnerable to be involved in sexual activities (Kumar Shashi et.al, 2013). Furthermore, Kraut et.al (1998) reported negative effects of using the internet on measures of social involvement. On the contrary, Kraut et al (2002) found the positive effects of using the internet on communication, social involvement and well-being. In all of these cases, it can be strongly expressed that Internet has a definite impact on the social development of adolescents as the new communication technologies enable youth to create and maintain social bonds in completely different ways.

Therefore, there is necessity to find out the relationship between cognitive, emotional intelligence and social development with Internet among the adolescents which has been a less significant concern till to date. However, it is found that the Internet advancement has considerable effects on the social life as well as cognitive development and emotional behaviours of the ASASIpintar students who are adolescents. Thus, there is an urge to conduct this research among the adolescents of the ASASIpintar. As it is believed that Internet advancement has inter-relationships with the cognitive, emotional and social development of the adolescents, this correlation has to be harnessed in positive ways to contribute to a wiser younger generation who is capable of adapting themselves to the erratic environment of modern technologies. As a long-term effect, this would finally lead to the quality members of the society and a holistic future generation as the asset of our country.

\section{PROBLEM STATEMENT}

In the era of science and technology, the number of people using the Internet has been increasing rampantly, especially among the adolescents. There are many online activities have attracted their attentions such as playing video games, surfing websites and social medias (Roberts et al, 2004). If this situation proceeds to the future, it is truly important to know the effects of the Internet advancement on the cognitive development, emotional intelligence and social development of the adolescents.

Based on the Pew Research Centre (2016) in 2015, it was found that $24 \%$ of teens go online "almost constantly," with the widespread usage of smartphones in the younger generation. It was also stated that the report shows more than half of the teens which consists of $56 \%$ whose ages are between 13 to 17 , go online several times a day and $12 \%$ of them once a day. At the same time, $6 \%$ of the teens go online weekly and $2 \%$ are even less often. In addition, the teens without smart phones tend to online less frequently compared to the others. Based on previous researches, it could be said that Internet could retard social development of adolescents whereby they form low quality friendships with strangers and thereby affecting their pre-existing offline relationships (Locke, 1998). Moreover, frequent use of the Internet to seek support and feedback from friends is capable of affecting the internal locus of control of adolescents (Chak $\&$ Leung, 2004). Furthermore, the usage of Internet indeed creates peer pressure among the adolescents to engage in risk tasking behaviours (McIntosh et.al, 2006) and negative feedbacks from Social Networking Service (SNS) could lower the self-esteem of the adolescents (Valkenburg and friends, 2006). The frequent users of the Internet tend to lack the emotional competence characteristic of high emotional intelligence, which constitutes an advantage for social adaption and may increase a sense of loneliness because usage becomes time-consuming and impairs normal functioning within the social and work-related realm leading to stress was reported by Elisabeth Engelgerg \& Lennart Sjoberg (2004). Other than that, cyber-bullying has also been proven to be the negative side of the Internet advancement to the adolescents whereby it provides a stage for online bullying, harassment, and humiliation (Strom \& Strom, 2005; Tokunaga, 2010).

Therefore, in accordance to the rapid development, it is certainly essential to find out the relationship between the cognitive, emotional intelligence and social enhancement in adolescent in responding to the Internet advancement. Since the adolescents are the future leaders of our country, there is an urge to know how their cognitive, emotional intelligence and social development are influenced throughout the revolution of the modern technologies such as the Internet, so that the younger generation are well-guided in utilising the technology in its best way

\section{RESEARCH QUESTION}

1. What is the level of Internet Addiction, Cognitive Development, Emotional Intelligence and Social Development among ASASIpintar students?

2. What is the relationship between Internet Addiction and Cognitive Development among ASASIpintar students?

3. What is the relationship between Internet Addiction and Emotional Intelligence among ASASIpintar students?

4. What is the relationship between Internet Addiction and Social Development among ASASIpintar students?

5. What is the relationship between Cognitive Development and Emotional Intelligence among ASASIpintar students?

6. What is the relationship between Cognitive Development and Social Development among ASASIpintar students?

7. What is the relationship between Emotional Intelligence and Social Development among ASASIpintar students?

\section{LITERATURE REVIEW}

\section{Internet Addiction and Emotional Intelligence among Adolescents}

For the relationship between emotional intelligence and Internet advancement, it was found that the usage of Social Networking Service (SNS) among the adolescents further complicates their relationship 
with their parents (Subrahmanyam \& Greenfield, 2008; Punamaki et.al, 2007). Another study found that social media use by adolescents has also been found to contribute to adolescent-parent conflicts leading to change in interactional patterns and sometimes to suicide (Shah et.al, 2016). Some adolescents are prone to develop symptoms of Internet addiction than others including those who experiences physiological symptoms and disorders such as depression, ADHD symptoms or hostility (Yen, 2007). Spending excessive amounts of time on SNSs on the Internet actually can lead to symptoms of depression and anxiety, which then increase the risk for social isolation (O'Keeffe, Pearson \& The Council on Communications and Media, 2011; Grieve et al., 2012; Jelenchick, Eickhoff, \& Moreno, 2013). Moreover, SNSs and social comparison adolescents may involve in social comparison, be it upward or downward which will have a strong impact on their self-esteem (Krayer, Ingledew, \& Iphofen, 2008) as well as comparing physical attractiveness online whereby female adolescents reporting a more negative body image after viewing beautiful versus less attractive pictures on SNS profiles (Hafercamp \& Kramer, 2011) and with more adolescents likely to post interesting, upbeat, and attention-grabbing details of their lives, online comparisons may be worse than it could be justified (Boyd \& Ellison, 2008). Another study on the emotional intelligence further suggests that the frequent use of the Internet affects the development of emotion regulation and autonomy which is crucial in identity development and influences later adjustment (Caprara, Gerbino et.al, 2010). On the other hand, a number of studies have shown that adolescents with excessive online gaming may display several symptoms of addiction, including being preoccupied by online games, causing various family and relationship problems, and experiencing mood modification (Griffiths et al., 2015). Besides, Ahmet Akin \& Murat Iskender (2011) examined the relationship between Internet addiction and anxiety, depression and stress and found a positive relationship. Furthermore, there is a significant relationship among emotional intelligence, mental disorders, and Internet addiction (Khoshakhlagh, 2014). The internet also has tremendous potential to affect the level of emotional intelligence of adolescents by affecting their emotions, and in turn alter their self-perception and anxiety levels (Petro van der Merwe, 2014). Prior researches had also proven the negative mental issues due to prolong usage of Internet among the youths such as poor physiological functioning and distress (Sampasa-Kanyinga \& Lewis, 2015), low self-esteem (Fiovaranti, Dettore, \& Casale, 2012), anxiety (Xiuqin et al.,2010), depression (van den Eijnden, Meerkerk, Vermulst et.al, 2008), loneliness and even suicidal ideation (Mitchell, Danielle et.al, 2015). In some of these limited studies, it has been also reported a negative association between some specific dimensions of emotion intelligence (e.g., self-management of emotions, social skills and empathy) and internet addiction (Oktan, 2011; Melchers et al., 2015). A study by Fariza Oskenbay \& Elmira Kalymbetova (2015) reported that Internet addiction among adolescents revealed negative influence of internet addiction to anxiety state of adolescents, their emotional sphere and personal traits. Nevertheless, some findings show that the usage of smart phones among the teenagers barely is the cause of changes in emotional behaviour such as depression in them (Sarah Rose Cavanagh, 2017). At the same time, certain parents utilize the SNSs to maintain their relationship with their children by being constantly connected to them via SNS of their choice despite some parents who are unaware of their teen's online activities (Kanter, Afifi \& Robbins, 2012) and some adolescents who has been using Facebook for more years and more hours per week agree on the statement that they were happier than they were before (Chou and Edge, 2012). However, overall, until to date, only a few numbers of studies were conducted to determine the relationship between emotional intelligence and Internet addiction of adolescents (Parker et al., 2008; van Deursen et al., 2015). Adolescents' social media use through the Internet improved both their ability to understand (cognitive empathy) and share the feelings of their peers (affective empathy) (Vossen \& Valkenburg, 2016). The results of the study conducted by Hemali Sanghvi \& Dr. Upagya Rai (2015) indicated that there is no significant correlation between Internet addiction and emotional intelligence.

\section{Internet Addiction and Social Development among Adolescents}

The following researches were conducted to show the correlation between the social development of adolescents with the Internet advancement. First of all, it was found that violent contents and interactive media such as video games can significantly encourage antisocial attitudes and aggressive tendencies among youths (Alessandro Gabbiadini et.al ,2013; Lin, 2013). Online communication also raises the tendencies of the adolescents becoming the prey of bullying and denotes an increase in cyber-bullying (Machmutow, Sticca, Alsakar \& Parren, 2012). Furthermore, it was reported that $68 \%$ of girls experiencing the negative effects of the social networking sites (Girl Scouts Study, 2010). Social Networking Sites (SNS) such as Facebook can develop fights, especially with the creation of "burn" pages created for reasons such as taunting or teasing others (Boyar, 2011). Frequent users of the Internet also spend more time on the internet instead of having a social life in the real world (Singh, 2010). Another study in the context of Internet use showed that extroverts are less inclined to solicit social services offered on the internet, presumably because their need for social exchange is sufficiently met offline (Correa, Hinsley, \& De Zuniga, 2010). Other than that, the usage of Internet to utilise the social medias might cause abusive relationships in which teenagers in relationships receive nude pictures of their partners or forced to send their nude pictures to their partners as well as receiving nonstop text messages or posting cruel comments on a boyfriend's or girlfriend's Facebook or MySpace page (Clifford, 2009). On the other hand, the interactive effect of Internet is that more online communication relates to more cohesive relationships (Lee, 2009). Moreover, adolescents' fantasies are given free rein, and the idea of being with their online friends can exceed all realistic expectations. Since few real-life relationships can compete with these wild, fantasy relationships, internet addicts will prefer to spend

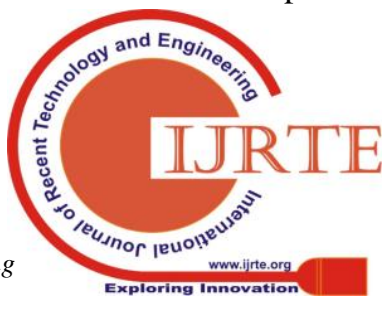


more and more time with their online friends (Dr. Petro van der Merwe, 2014). The frequent usage of Internet for the social networking sites is related to the level of friendship whereby resulting quality relationships and intimacy with enhanced social connections (Ellison, Steinfield, \& Lampe, 2007; Grieve, Indian, Witteveen, Tolan, \& Marrington, 2012; Reich, Subrahmanyam, \& Espinoza, 2012). Excitingly, Korean SNS users with high social identity found SNSs to be a good resource for social support (Kwon \& Wen, 2010) and in younger participants, there was $43 \%$ of high school students who believed that SNS in the Internet helps them to become more closer to friends (Reich et.al, 2012). However, $20 \%$ college students indicated that SNSs brought them closer to their friends while $2.5 \%$ said it had negative impacts but the majority of $73 \%$ claimed that SNSs use did not have an effect on their relationships (Subrahmanyam et al., 2008). Moreover, focusing on early adolescents' sense of belongingness, a highly salient social construct for adolescents, showed that in a sample of young students in north England, the SNS use to provide a great sense of belongingness in the boys rather than girls (Quinn \& Oldmeadow, 2013). Adolescents with depression also were said to benefit more from online communication than face-to-face communication due to anonymity and less worry about privacy and stigma because they could connect with other people with the same mental illness and seek advices and support from them as well as reduce social isolation (Naslund, et.al 2014). There is also study showing adolescents with depressive symptoms experiencing peer victimization on Facebook but social support could be a protective factor (Frison et al., 2016).

\section{Cognitive Development and Emotional Intelligence among Adolescents}

For the correlation between cognitive development and emotional intelligence, from a sample of 169 adolescent students from different academic backgrounds, adolescents with high cognitive ability has a higher capability in managing their emotional self-efficacy compared to the low achievers (Puspalatha Armum \& Kalaivani Chellapan, 2015). It was also found that there is a positive correlation between the sub-component of EI which is empathy and academic score (Sekhri et.al, 2017) as well as the overall level of emotional intelligence. The academic achievement of students for English learning was also shown to have enhanced with an increase in emotional intelligence in Tehran by secondary school students (Akram et.al, 2016). Nevertheless, this contradicts with a study that shows no significant correlation between emotional intelligence of high school students and their academic achievement (Lawrence et.al, 2013). On the contrary, a study in London showed that cognitive ability was significantly correlated with all five EQ subscales as well as the total EQ score (Furnham, 2016). Furthermore, students with high level for EQ sub-components such as self-awareness, self-management and social awareness does not necessarily get good academic result or vice versa (Kasa et.al, 2013; Lotfi Kashani, 2012) and at the same time, emotional intelligence was shown not to be the significant predictor of school success (Matešić, 2015).

\section{Cognitive Development and Social Development among Adolescents}

The following is the correlation between the cognitive development and social development among the adolescents. Recently, brain imaging experiments have proven that changes in social cognition upon reaching puberty are closely related to brain development (Burnett and Blakemore, 2009). Moreover, data obtained from other researches also suggest that the efficiency and possibly strategy of perspective taking improve together with brain maturation and psychological development during adolescence (Choudhury et.al, 2006). At the same time, there was also a positive relationship between social skills such as assertion and self-control with academic achievements (Guimarães et.al, 2011). Nevertheless, study with opposite result was also obtained whereby it was shown that academic achievement did not correlate with social intelligence (Meijs et.al, 2008) .

\section{Emotional Intelligence and Social Development among Adolescents}

On the other hand, for the relationship between emotional intelligence and social development, there was a study showing trait EI was positively associated with peer-rated social competence, especially prosocial behaviour whereby high trait EI adolescents possess and exhibit social skills that are easily detected by their peers (Mavroveli et.al, 2007). It was also shown that there is a relationship between emotional intelligence and the sub-component of social development which is communication skills of participants (Nouri et.al, 2014) and the overall social skills (Al-Tamimi et.al, 2016). Moreover, high scores on the managing emotions subscale of the MSCEIT were associated with higher quality of relationships with friends (Lopes et.al, 2019). It was found that there is an insignificant difference between social and emotional self-efficacy across the gender (Puspalatha Armum \& Kalaivani Chellapan, 2015).

\section{METHODOLOGY}

\section{Participants}

This study focused on the 130 students of ASASIpintar who have been doing their one-year foundation program in the National University of Malaysia for the session 2018/2019. The total population comprises of both genders, male and female and sums up to a total of 190 students who are adolescents at the age between 17 and 18 years old. However, only 130 students were chosen for the research as the sample according to the 'Table for Determining Sample Size from a Given Population for Research Activities' by Krejcie, Robertv, Morgan \& Daryle W. (1970). This was due to time constraint as well as to provide more convenience for the execution of the research. This survey was conducted during their 2nd semester session

\section{A. Research Design}

This research is a quantitative study whereby correlation design was used. This is because the researcher intended to find out the relationship between several variables such as the association between 
Cognitive Development, Emotional Intelligence and Social Development in accordance to the Internet Advancement. Thus, the independent variable is the addictive usage of Internet among the adolescents of ASASIpintar and the dependent variables are their cognitive, emotional intelligence and social development. By using this design, it enabled the researcher to test the hypothesis made earlier across these wide range of variables. Not only that, this design enabled the researcher to use the standardized procedures for questions and answers which was a very convenient method in order to collect the required data. As a result, the survey interviewing method using questionnaires could be applied to a large number of respondents (130 students) and the data obtained could be analysed in a more appropriate way. The data collected was analysed using the SPSS Software, Version 23.

\section{B. Sampling Technique}

To collect the data in this study, the stratified random sampling technique was applied. The population was divided into two groups known as strata according to their genders, males and females. As mentioned above, a total number of 130 students were selected as the samples from these two major groups which comprises of 65 males and 65 females. This was done because of the number of male and female students of ASASIpintar are not equally distributed whereby there are only 80 males but 110 females. Thus, by using this technique (stratified random sampling), a fair result could be attained by avoiding any biased situations. Not only that, this technique was also chosen due another reason which was that the one of the objectives of the research was to see the difference between the level of Internet Addiction among the male and female adolescents of the ASASIpintar. Hence, an equal number of male and female adolescents were required as the sample to reduce any errors pertaining unequal distribution, leading to a non-reliable result. Therefore, those 65 males and females were randomly picked whereby every one of them had an opportunity to be selected as the sample. This was done by using the online random generator named 'Stat Trek'.

\section{Pilot Test}

Table 1: Cronbach Alpha for Pilot Test

\begin{tabular}{cc}
\hline Instrument & Cronbach Alpha \\
\hline Internet Addiction Test (IAT) & .908 \\
Working Memory & .935 \\
Questionnaire (WMQ) & \\
Trait Emotional Intelligence \\
Questionnaire (TEI-Que)
\end{tabular}

Table 1 show the Cronbach Alpha for the Pilot Test done for the all four instruments namely; Internet Addiction (IAT), Working Memory Questionnaire (WMQ), Trait Emotional Intelligence Questionnaire (TEI-Que) and Social
Self-Efficacy Scale (SSES). The sample for the pilot test was 50 students of ASASIpintar who were selected randomly using 'Stat Trek' and the test was conducted using the SPSS Software, Version 23 during the First Semester holiday. The same procedure to collect the data for the actual test was applied in the pilot test whereby the questionnaire was created using the Google Form and the link was distributed individually through the link on WhatsApp application. The students were given about two weeks for the completion and submission of the forms.

\section{FINDINGS}

To determine Level of Internet Addiction, Cognitive Development, Emotional Intelligence and Social Development

Table 1: Level of Internet Addiction, Cognitive Development, Emotional Intelligence and Social Development

\begin{tabular}{lll}
\hline Variable & Mean & $\begin{array}{l}\text { Standard } \\
\text { deviation }\end{array}$ \\
\hline $\begin{array}{l}\text { Internet } \\
\text { Addiction }\end{array}$ & 2.5817 & .82742 \\
Working Memory & 2.5018 & .75168 \\
$\begin{array}{l}\text { Emotional } \\
\text { Intelligence }\end{array}$ & 4.3272 & .67784 \\
$\begin{array}{l}\text { Social } \\
\text { Development }\end{array}$ & 3.4875 & .66833 \\
& & \\
\hline
\end{tabular}

Table 1 shows the mean of the level Internet Addiction, Cognitive Development, Emotional Intelligence and Social Development among the students of ASASIpintar. According to the mean interests by Wiersma (1995), the value from 1.00 to 2.33 represents weak levels, 2.34 to 3.67 indicates a moderate level whereas 3.68 to 5.00 is considered to be high. According to Table 2, the level of Internet Addiction, Cognitive Development and Social Development among the students of ASASIpintar is moderate (Mean= $2.5817,2.5018$ and 3.4875 respectively). However, the students of ASASIpintar has a high level of Emotional Intelligence $($ Mean $=4.3272)$.

To Determine the Relationship between Internet Addiction and Emotional Intelligence among ASASIpintar Students 
Table 2: Relationship between Internet Addiction and Emotional Intelligence

\begin{tabular}{|c|c|c|c|}
\hline \multicolumn{2}{|l|}{ Variable } & $\begin{array}{l}\text { Internet } \\
\text { Addiction }\end{array}$ & $\begin{array}{l}\text { Emotional } \\
\text { Intelligence }\end{array}$ \\
\hline \multirow[t]{3}{*}{$\begin{array}{l}\text { Internet } \\
\text { Addiction }\end{array}$} & $\begin{array}{l}\text { Pearson } \\
\text { Correlation }\end{array}$ & 1 & -.389 \\
\hline & $\begin{array}{l}\text { Sig. } \\
\text { (2-tailed) }\end{array}$ & & .000 \\
\hline & $\mathrm{N}$ & 130 & 130 \\
\hline \multirow[t]{3}{*}{$\begin{array}{l}\text { Emotional } \\
\text { Intelligence }\end{array}$} & $\begin{array}{l}\text { Pearson } \\
\text { Correlation }\end{array}$ & -.389 & 1 \\
\hline & $\begin{array}{l}\text { Sig. } \\
\text { (2-tailed) }\end{array}$ & .000 & \\
\hline & $\mathrm{N}$ & 130 & 130 \\
\hline
\end{tabular}

Correlation is significant at the 0.01 level (2-tailed)

Table 2 above shows the correlation between the level of Internet Addiction and the level of Emotional Intelligence. According to the results, the Pearson Correlation between Internet Addiction and Emotional Intelligence is $r=-0.389$ whereas the p-value of two-tailed test of significance is 0.000 The result of correlation coefficient of $r=-0.389$ indicates that the Internet Addiction has a weak negative correlation with Emotional Intelligence. The correlation is significant since the p-value does not exceed the value of significance of 0.05 .

\section{To Determine the Relationship between Internet Addiction and Social Development among ASASIpintar Students}

Table 3: Relationship between Internet Addiction and Social Development

\begin{tabular}{l|l|c|c}
\hline \multicolumn{2}{l|}{ Variable } & $\begin{array}{c}\text { Internet } \\
\text { Addiction }\end{array}$ & $\begin{array}{c}\text { Social } \\
\text { Development }\end{array}$ \\
\hline $\begin{array}{l}\text { Internet } \\
\text { Addiction }\end{array}$ & $\begin{array}{l}\text { Pearson } \\
\text { Correlation }\end{array}$ & 1 & -.111 \\
\cline { 2 - 4 } & $\begin{array}{l}\text { Sig. } \\
(2 \text {-tailed })\end{array}$ & & .209 \\
\cline { 2 - 3 } $\begin{array}{l}\text { Social } \\
\text { Development }\end{array}$ & $\begin{array}{l}\text { Nearson } \\
\text { Correlation }\end{array}$ & -.111 & 130 \\
\cline { 3 - 4 } & $\begin{array}{l}\text { Sig. } \\
(2-t a i l e d)\end{array}$ & .209 & \multirow{2}{*}{130} \\
\cline { 3 - 4 } & N & 130 & \multirow{2}{*}{130} \\
\hline
\end{tabular}

Correlation is significant at the 0.01 level (2-tailed)
Table 3 above shows the correlation between the level of Internet Addiction and the level of Social Development. According to the results, the Pearson Correlation between Internet Addiction and Social Development is $r=-0.111$ whereas the p-value of two-tailed test of significance is 0.209 . The result of correlation coefficient of $r=-0.111$ indicates that the Internet Addiction has a very weak negative correlation with Social Development. The correlation is not significant since the p-value exceeds the value of significance of 0.05 .

To Determine the Relationship between Cognitive Development and Emotional Intelligence among ASASIpintar Students

Table 4: Relationship between Cognitive Development and Emotional Intelligence

\begin{tabular}{|c|c|c|c|}
\hline \multicolumn{2}{|l|}{ Variable } & \multirow{2}{*}{$\begin{array}{l}\text { Working } \\
\text { Memory }\end{array}$} & \multirow{2}{*}{$\begin{array}{l}\begin{array}{l}\text { Emotional } \\
\text { Intelligence }\end{array} \\
.498\end{array}$} \\
\hline $\begin{array}{l}\text { Working } \\
\text { Memory }\end{array}$ & $\begin{array}{l}\text { Pearson } \\
\text { Correlation }\end{array}$ & & \\
\hline & $\begin{array}{l}\text { Sig. } \\
\text { (2-tailed) }\end{array}$ & & .000 \\
\hline & $\mathrm{N}$ & 130 & 130 \\
\hline \multirow[t]{3}{*}{$\begin{array}{l}\text { Emotional } \\
\text { Intelligence }\end{array}$} & $\begin{array}{l}\text { Pearson } \\
\text { Correlation }\end{array}$ & .498 & 1 \\
\hline & $\begin{array}{l}\text { Sig. } \\
\text { (2-tailed) }\end{array}$ & .000 & \\
\hline & $\mathrm{N}$ & 130 & 130 \\
\hline
\end{tabular}

Correlation is significant at the 0.01 level (2-tailed)

Table 4 above shows the correlation between the level of Cognitive Development and the level of Emotional Intelligence. According to the results, the Pearson Correlation between Cognitive Development and Emotional Intelligence is $r=0.498$ whereas the $p$-value of two-tailed test of significance is 0.000 . The result of correlation coefficient of $r=0.498$ indicates that the Cognitive Development has a moderate positive correlation with Emotional Intelligence. The correlation is significant since the p-value does not exceed the value of significance of 0.05 .

To Determine the Relationship between Cognitive Development and Social Development among ASASIpintar Students 
Table 5: Relationship between Cognitive Development and Social Development

\begin{tabular}{|c|c|c|c|}
\hline \multicolumn{2}{|l|}{ Variable } & \multirow{2}{*}{$\begin{array}{l}\text { Working } \\
\text { Memory }\end{array}$} & \multirow{2}{*}{$\begin{array}{l}\begin{array}{l}\text { Social } \\
\text { Development }\end{array} \\
.314\end{array}$} \\
\hline $\begin{array}{l}\text { Working } \\
\text { Memory }\end{array}$ & $\begin{array}{l}\text { Pearson } \\
\text { Correlation }\end{array}$ & & \\
\hline \multirow{5}{*}{$\begin{array}{l}\text { Social } \\
\text { Development }\end{array}$} & $\begin{array}{l}\text { Sig. } \\
\text { (2-tailed) }\end{array}$ & & .000 \\
\hline & $\mathrm{N}$ & 130 & 130 \\
\hline & $\begin{array}{l}\text { Pearson } \\
\text { Correlation }\end{array}$ & .314 & 1 \\
\hline & $\begin{array}{l}\text { Sig. } \\
\text { (2-tailed) }\end{array}$ & .000 & \\
\hline & $\mathrm{N}$ & 130 & 130 \\
\hline
\end{tabular}

Correlation is significant at the 0.01 level (2-tailed)

Table 5 above shows the correlation between the level of Cognitive Development and the level Social Development. According to the results, the Pearson Correlation between Cognitive Development and Social Development is $r=0.314$ whereas the $\mathrm{p}$-value of two-tailed test of significance is 0.000 . The result of correlation coefficient of $r=0.314$ indicates that the Cognitive Development has a weak positive correlation with Social Development. The correlation is significant since the p-value does not exceed the value of significance of 0.05 .

To Determine the Relationship between Emotional Intelligence and Social Development among ASASIpintar Students

Table 6: Relationship between Emotional Intelligence and Social Development

\begin{tabular}{l|l|l|l}
\hline \multicolumn{2}{l|}{ Variable } & $\begin{array}{l}\text { Emotional } \\
\text { Intelligence }\end{array}$ & $\begin{array}{l}\text { Social } \\
\text { Development }\end{array}$ \\
\hline $\begin{array}{l}\text { Emotional } \\
\text { Intelligence }\end{array}$ & $\begin{array}{l}\text { Pearson } \\
\text { Correlati } \\
\text { on }\end{array}$ & 1 & .563 \\
\cline { 2 - 4 } & $\begin{array}{l}\text { Sig. } \\
\text { (2-tailed) }\end{array}$ & & .000 \\
\cline { 2 - 4 } $\begin{array}{l}\text { Social } \\
\text { Development }\end{array}$ & $\begin{array}{l}\text { Pearson } \\
\text { Correlati } \\
\text { on } \\
\text { Sig. } \\
\text { (2-tailed })\end{array}$ & .563 & 130 \\
\cline { 2 - 4 } & N & 130 & 130 \\
\cline { 2 - 4 } & .000 & 130 \\
\cline { 2 - 4 } & &
\end{tabular}

Correlation is significant at the 0.01 level (2-tailed)

Table 6 above shows the correlation between the level of Emotional Intelligence and the level Social Development. According to the results, the Pearson Correlation between Emotional Intelligence and Social Development is $r=0.563$ whereas the p-value of two-tailed test of significance is 0.000 . The result of correlation coefficient of $r=0.563$ indicates that the Emotional Intelligence has a moderate positive correlation with Social Development. The correlation is significant since the p-value does not exceed the value of significance of 0.05 .

\section{DISCUSSION}

Based on the results obtained, it was found that the adolescents of ASASIpintar has a moderate level of Internet Addiction. This is supported by Kaiser Foundation (2010) who thinks that adolescents spend approximately their half day on electronic media. Besides, Pempek, Yermolayeva \& Calvert (2009), also found that adolescents spend half an hour every day on Facebook and basically most time on social networking sites (Lenhart, 2009; Lenhart, 2012; Lenhart et.al, 2010) which could be evident by 7.5 million adolescents having Facebook accounts ("That Facebook Friend", 2011). Furthermore, based on another research by Heo, Oh, Subramanian and friends (2014), it was found that Internet addiction among youth as a major problem in the country (Heo, Oh, Subramanian and friends, 2014). As strengthening evidence for the result, it was found that adolescents of age between 17 to 18 years old has a moderate level $(13 \%)$ of Internet addiction (Karacic et.al, 2017) and another study revealed that $70.5 \%$ of adolescents were normal users (Kayastha et.al, 2018) as well as another research showing an overall mild addiction between adolescents (Xin et.al, 2018). In addition, there was also two third of the adolescents reached the average score for Internet addiction in a study (Rębisz et.al, 2016). Besides, this study also predicts that the students of ASASIpintar has moderate level of cognitive development. This is strongly supported by the average level of academic achievement among high school students in Kanyakumari district (Lawrence et.al, 2013). In this research, it was obtained that the students of ASASIpintar has a high level of emotional intelligence. This is supported by a previous research also done among different group of adolescents of ASASIpintar, showing a high level of emotional intelligence (Elmi, 2018) and nearly $50 \%$ of grade eight students in Embilipitiya educational zone had a good level of emotional intelligence (Lankashini et.al, 2017). A considerably good level of self-awareness, self-management and social awareness among all the students in a private higher institution of Kuching, Sarawak (Kasa et.al, 2013) that supports the result obtained and an average level of emotional intelligence of the high school students in Kanyakumari district (Lawrence et.al, 2013). This study also indicates that the students of ASASIpintar has a moderate level of social development. This is supported by a study with a moderate level of 
communication skills among the high school students in Hamadan (Nouri et.al, 2014).

According to the results obtained in this research, there is also a weak negative correlation between the emotional intelligence and the level of Internet addiction of adolescents. This suggest that the higher the level of emotional intelligence of an adolescent, the lower it is his level of Internet addiction. This is shown by certain researches whereby complicating relationship between parents and adolescents arise from high usage of social networking sites (Subrahmanyam \& Greenfield, 2008; Punamaki et.al, 2007, (Shah, Chauhan et.al, 2016). Moreover, adolescents with physiological disorders like depression or hostility are more likely to develop Internet addiction (Yen et.al, 2007) and excessive use of Internet may lead to anxiety that increases the risk of social isolation (O'Keeffe, Pearson \& The Council on Communications and Media, 2011; Grieve et al., 2012; Jelenchick, Eickhoff, \& Moreno, 2013) as well as affect their self-esteem (Krayer, Ingledew, \& Iphofen, 2008). This is also supported by Hafercamp \& Kramer (2011) who found out that negative body image is portrayed by female adolescents who compares beautiful and less attractive images on social networking sites as well as adolescents posting details of their lives making online comparisons possible and thus affecting the emotional intelligence of another group of adolescents (Boyd \& Ellison, 2008). It has been also reported a negative association between some specific dimensions of emotion intelligence (e.g., self-management of emotions, social skills and empathy) and Internet addiction (Oktan, 2011; Melchers et al., 2015). There was also a study showing Internet addiction affects emotion regulation and autonomy which is important in identity development and influences later adjustments (Caprara, Gerbino et.al, 2010) and online gaming which causes Internet addiction may lead to various family and relationship problems, and experiencing mood modification (Griffiths et al., 2015). A positive relationship that shows the higher the Internet addiction, the higher the level of depression van den Eijnden, Meerkerk, Vermulst et.al, 2008), anxiety (Xiuqin et al.,2010; Fariza Oskenbay and Elmira Kalymbetova, 2015) and stress (Sampasa-Kanyinga \& Lewis, 2015) was examined by Ahmet Akin and Murat Iskender (2011). There is also a significant relationship between emotional intelligence, mental disorders and Internet addiction (Khoshakhlagh, 2014) as well as on the self-perception, self-esteem (Fiovaranti, Dettore, \& Casale, 2012) and anxiety levels (Dr. Petro van der Merwe, 2014) or even causes loneliness and even suicidal ideation (Mitchell, Danielle et.al, 2015). However, the result obtained in this research contradicts with some of the researchers like Sarah Rose Cavanagh (2017) who founds that the usage of smart phone among teenagers is barely the cause for the changes in their emotional behaviour. A positive correlation between Internet addiction and emotional intelligence was also shown through certain findings whereby parents utilize the SNSs to keep in touch with their children which improves their relationship (Kanter, Afifi \& Robbins, 2012) and also certain adolescents find themselves happier than before after using Facebook (Chou \& Edge, 2012). Another finding that contradicts is that adolescents' Internet addiction to social media improved both their ability to understand (cognitive empathy) and share the feelings of their peers (affective empathy) (Vossen \& Valkenburg, 2016) as well as the study conducted by Hemali Sanghvi \& Dr. Upagya Rai (2015) indicated that there is no significant correlation between Internet addiction and emotional intelligence.

The following is also a very weak negative correlation between the social development of the adolescents and the level of Internet addiction as obtained from the results. This is supported by a study that shows Internet addiction to video games with violent content can lead to antisocial attitudes and aggressive tendencies among youths (Alessandro Gabbiadini et.al 2013; Lin, 2013) and online communication increases the chances of cyber-bullying (Machmutow, et.al 2012). Besides, Social Networking Sites (SNS) such as Facebook can develop fights through taunting or teasing others (Boyar, 2011) and Inter addicts also spend more time on the Internet instead of having a social life in the real world (Singh, 2010). In addition, extroverts are less addicted to the Internet because their need for social exchange is sufficiently met offline (Correa, Hinsley, \& De Zuniga, 2010) and teenagers addicted to social medias through the Internet might involve in abusive relationships (Clifford, 2009). On the contrary to the results obtained, certain researches provide that there is a positive correlation between social development and the level of Internet addiction. One of them is that more online communication relates to more cohesive relationships (Lee, 2009). Other than that, Internet addicts spend more time with online friends, enhancing their social skills and forming wild, fantasy relationships which exceeds the realistic expectations (Dr. Petro van der Merwe, 2014) and results in quality relationships with enhanced social connections (Ellison, Steinfield, \& Lampe, 2007; Grieve, Indian, Witteveen, Tolan, \& Marrington, 2012; Reich, Subrahmanyam, \& Espinoza, 2012). Furthermore, Korean SNS users found the social networking sites to be a good resource for social support (Kwon \& Wen, 2010) and help them to become more closer to their friends (Reich et.al, 2012). However, there is also a finding showing that majority of the college students claimed social networking site does not have an effect on their relationships (Subrahmanyam et al., 2008). For those adolescents facing depression, Internet helps to enhance their communication skills through online instead of face-to-face communication and thus, reducing social isolation (Naslund, Grande, and friends, 2014) as well as help them to gain social support (Frison et al., 2016).

Other than that, it was obtained from this research that there is a moderate positive correlation between emotional intelligence and cognitive development. This was shown in a research done by Puspalatha

Armum and Kalaivani Chellapan (2015) proves that adolescents with high 
cognitive ability has a higher capability in managing their emotional self-efficacy compared to the low achievers. This is supported by a study that shows a significant positive correlation between academic score and emotional intelligence, more specifically empathy (Sekhri et.al, 2017) especially for English learning in Tehran by secondary school students (Akram et.al, 2016) but contradicts with a study that shows no significant correlation between emotional intelligence of high school students and their academic achievement (Lawrence et.al, 2013). Another contradicting study also shows that cognitive ability is significantly negatively correlated with all the five EQ subscales as well as the total EQ score (Furnham, 2016). In addition to that, student who possess high level of self-awareness, self-management and social awareness are not likely to get good academic result (Kasa et.al, 2013; Lotfi Kashani, 2012) and emotional intelligence was not shown to be significant predictor of school success (Matešić, 2015).

Furthermore, the result shows a weak positive correlation between the cognitive development and social development among the adolescents. This is strongly supported by brain imaging experiments that have shown the changes in social cognition post puberty are also related to brain development (Burnett \& Blakemore, 2009) and parallel development of efficiency and possibly strategy of perspective taking with brain maturation and psychosocial development during adolescence (Choudhury et.al, 2006). There is also a positive association that relates social skills such as assertion and self-control with academic results (Guimarães et.al, 2011). However, another finding shows that academic achievement did not correlate with social intelligence (Meijs et.al, 2008)

Moreover, it is shown by the result that there is a moderate positive correlation between emotional intelligence and social development. This is supported by a research whereby trait EI was positively associated with peer-rated social competence, especially prosocial behaviour (Mavroveli et.al, 2007) and another study showing a significant relationship between emotional intelligence and communication skills (Nouri et.al, 2014) of the participants and overall social skills (Al-Tamimi et.al, 2016). In addition, high level of emotional intelligence leads to higher quality of relationship with friends (Lopes et.al, 2019).

\section{CONCLUSION}

The moderate level of Internet addiction among the ASASIpintar students indicates that the students are capable of maintaining a healthy lifestyle by not totally indulging in the modern technology. However, appropriate measures have to be taken by parents and the college administration, so that there is no continuous rise in their usage of Internet that may lead to higher addiction level. There is also no difference among the males and females of ASASIpintar in their level of Internet Addiction, proving that both males and females are prone to be Internet addicted if they do not have proper self-control over their Internet usage. At the same time, it is necessary to improve the moderate level of cognitive development and social development among the ASASIpintar students through proper activities that encourage social interaction as well as includes perception and skills on problem solving, so that they could live a harmony life with students of diverse backgrounds. The high level of emotional intelligence among the students of ASASIpintar signifies their ability to control and regulate their emotions as well as understand the emotions of the others. Besides, the correlation between cognitive development and Internet addiction proves that students of ASASIpintar should limit their Internet usage since poor executive control contributes the most to the level of Internet addiction, so that their cognitive development is not affected which in turn will result in a better academic performance. Similarly, the correlation between the level of emotional intelligence and Internet addiction shows that students with high level of emotional intelligence are capable of self-regulation and thus they do not spend time excessively or unnecessarily on the Internet. The social development of the ASASIpintar students is also influenced by their level of Internet addiction whereby students who are highly addicted, avoid being socially active in real life. Moreover, high level of emotional intelligence and social development also correlates with the high level of cognitive development among the ASASIpintar students since with high EQ and social ability, the students could easily maintain a balanced mental health by communicating effectively to express their feelings and thoughts which would definitely contribute to their cognitive development. Lastly, emotional intelligence is closely related to social development of the ASASIpintar students because students with high EQ has high empathy towards others who suffer from problems, so they interact and foster bonds with them to alleviate their predicaments, thus increasing their ability to socialize.

\section{REFERENCES}

1. Peterson C. Looking forward through childhood and adolescence. Forest, NSW: Pearson Education Australia; 2004.

2. Christie D, Viner R. Adolescent development. BMJ 2005;330:301-4.

3. Ramalingam A, Kar SS. Is there a digital divide among school students? An exploratory study from Puducherry. J Educ Health Promot 2014:3.

4. Kagu B. The effect of group counselling on study habit patterns of adult learners. The Counsellor 2000;18:148-55.

5. Markey PM, Wells SM. Interpersonal perception in internet chat rooms. J Res Personality 2002;36:134-46.

6. Bayraktar F, Gün Z. Incidence and correlates of internet usage among adolescents in North Cyprus. Cyberpsychol Behav 2007;10:191-7.

7. Internet. (n.d.). Retrieved July 23, 2018, from https://en.wikipedia.org/wiki/Internet

8. Quigley, M. \& Blashki, K. (2003) Beyond the Boundaries of the Sacred Garden: children and the Internet, Educational Technology Review, 11, pp. 70-77

9. Chubb P. Facebook dethrones myspace: New 2010 statistics. 2010 Retrieved from http://www.product-reviews.net/2010/11/21/facebook-dethrones-m yspace-new-2010-statistics/

10. Roberts, D. F., Foehr, U. G., \& Rideout, V. (2004). Generation M: Media in the lives of $8-18$ year olds. Menlo Park, CA: The Henry J. Kaiser Family Foundation. Available at http://www.kff.org/entmedia/loader.cfm?url=/commonspot/security /getfile.cfm\&PagelD=51809

11. Nie NH, Erbring L. Internet and society: a preliminary report. 2000. Available from: 
URL: http://sd-cite.iisd.org/cgi-bin/koha/opac-detail.pl?biblionumbe $r=16273 /$

12. Robinson, T. E., \& Kolb, B. (2004). Structural plasticity associated with exposure to drugs of abuse. Neuropharmacology, 47, 33-46

13. Das, J. P., \& Naglieri, J. A. (2001). The Das-Naglieri cognitive assessment system in theory and practice. In J. J. W. Andrews, D. H Sakolfske, \& H. L. Janzen (Eds.), Handbook of psychoeducational assessment: Ability, achievement, and behavior in children (pp. 34-64) San Diego, CA: Academic Press.

14. Solso, R. L., MacLin, M. K., \& MacLin, O. H. (2005). Cognitive psychology (7th ed). Boston, MA: Allyn and Bacon.

15. Sweller, J. (1988). Cognitive load during problem solving: Effects on learning. Cognitive Science, 12, 257-285.

16. Bandura, A. (1978). Perceived effectiveness: An explanatory mechanism of behavioral change. In G. Lindzey, C. S. Hall, \& R. F. Thompson (Eds.) Psychology. New York: Worth.

17. Luria, A. R. (1973). The working brain. Harmondsworth, England: Penguin.

18. Luria, A. R. (1976). Cognitive development: Its cultural and social foundations. Cambridge MA: Harvard University Press.

19. Goleman, D. (1996). La Inteligencia Emocional. Por qué es más importante que el cociente intelectual. España: Javier Vergara Editor S.A.

20. Goleman, D. 2004. Emotional Intelligence: Why it can matter more than IQ \& Working with Emotional Intelligence. London, UK: Bloomsbury Publishing.

21. Mayer, J. D., Carsuo, D. R. \& Salovey, P., (2000). Models of Emotional Intelligence In R. Sternberg (Ed.) Handbook of Intelligence, Cambridge University Press, Cambridge, UK.

22. Salovey, P., \& Mayer, J. D. (1990). Emotional intelligence. Imagination, Cognition, and Personality, 9, 185-211.

23. Segal, J. 2008. The Language of Emotional Intelligence: The Five key skills for building powerful and effective relationships. New York: McGraw Hill.

24. Parker JDA, Taylor RN, Eastabrook JM; et al. Problem gambling in adolescence: relationships with internet misuse, gaming abuse and emotional intelligence. Pers Indiv Differ. 2008, 45:174-180.

25. Cecen AR. School alienation: Gender, socio-economic status, and anger in high school adolescents. Kuram ve Uygulamada Egitim Bilimleri. 2006;6:721-726. Retrieved

from http://www.scimagojr.com/journalsearch.php?q=19500157110\&tip= sid\&clean $=0$.

26. Subrahmanyam, K., \& Greenfield, P. (2008). Online Communication and Child Relationships. [Electronic version]. Online Communication and Child Relationship, 18(1), 119-146.

27. Mesch, Gustavo S. 2006. "Family Relations and the Internet: Exploring a Family Boundaries Approach." The Journal of Family Location 6(2):119-138. Retrieved $\quad$ February 22, 2012 (http://web.ebscohost.com.jproxy.nuim.ie/ehost/pdfviewer/pdfviewer?sid =b66230f0-

a. ad5d-4aed-ad99-f81 f0129aa0c\%40sessionmgr104\&vid=4\&hid=110)

28. Lee SJ. Online communication and adolescent social ties: who benefits more from Internet use? Journal of Computer-Mediated Communication. 2009;14(3):509-531.

29. Beebe TJ, Asche SE, Harrison PA, Quinlan KB. Heightened vulnerability and increased risk-taking among adolescent chat room users: Results from a statewide school survey. J Adolesc Health 2004;35:116-23.

30. Markey PM, Wells SM. Interpersonal perception in internet chat rooms. J Res Personality 2002;36:134-46.

31. Mesch GS, Social relationships and internet use among adolescents in Israel. Soc Sci Quart 2001;82:329-39.

32. Saklofske, D. H., Austin, E. J., \& Minski, P. S. (2003). Factor structure and validity of a trait emotional intelligence measure. Personality and Individual Differences, 34, 707-721.

33. Van Rooy, D., Alonso, A. and Viswesvaran, C. (2005) Group Differences in Emotional Intelligence Scores: Theoretical and Practical Implications. Personality and Individual Differences, 38, 689-700.

34. Kong, F., Zhao, J., \& You, X. (2012). Social support mediates the influence of emotional intelligence on mental distress and life satisfaction in Chinese young adults. Personality and Individual Differences, 53 , 513-517. http://dx.doi.org/10.1016/j.paid.2012.04.021

35. Mikolajczak, M., Luminet, O., Leroy, C., \& Roy, E. (2007). Psychometric properties of the trait emotional intelligence questionnaire: Factor structure, reliability, construct, and incremental validity in a French-speaking population. Journal of Personality Assessment, 88(3), 338-353

http://dx.doi.org/10.1080/00223890701333431

36. Shi, J., \& Wang, L. (2007). Validation of emotional intelligence scale in Chinese university students. Personality and Individual Differences, 43 377-387. http://dx.doi.org/10.1016/j.paid.2006.12.012
37. Wolak, J., Mitchell, K. J., \& Finkelhor, D. (2003). Escaping or connecting? Characteristics of youth who form close online relationships Journal of Adolescence, 26(1), 105-119.

38. Kumar Shashi, Das RC, Prabhu HRA, Bhat PS, Prakash Jyoti, Seema P et al. Interaction of media, sexual activity and academic achievement in adolescents. Med J Armed Forces India 2013;69:138-43.

39. Kraut, R. E., Patterson, M., Lundmark, V., Kiesler, S., Mukhopadhyay, T., \& Scherlis, W. (1998). Internet paradox: A social technology that reduces social involvement and psychological well-being? American Psychologist, 53, 1017, 1998

40. Kraut, R., Kiesler, S., Boneva, B., Cummings, J., Helgeson, V., \& Crawford, A. (2002) 'Internet paradox revisited', Journal of Social Issues, vol. 58, pp. 49-74.

41. Kaiser Family Foundation. Total media exposure, by age. Media and Health. 2010 Retrieved from: http://facts.kff.org/chart.aspx?ch=1368.

42. Pempek TA, Yermolayeva YA, Calvert SL. College students' socia networking experiences on Facebook. Journal of Applied Developmenta Psychology. 2009;30:227-238

43. Lenhart A. Teens and mobile phones over the past five years: Pew Internet looks back. Pew Internet and American Life Project. 2009:1-17. Retrieved from: http://www.pewinternet.org/Reports/2007/Social-Networking-Websi tes-and-Teens.aspx.

44. Lenhart A. Teens, smartphones, and texting. Pew Internet and American Life Project. 2012:1-34. Retrieved from: http://pewinternet.org/ /media//Files/Reports/2012/PIP Teens Sma rtphones and Texting.pdf.

45. Lenhart A, Ling R, Campbell S, Purcell K. Teens and mobile phones. Pew Internet and American Life Project. 2010:1-94. Retrieved from: http://pewinternet.org/Reports/2010/Teens-and-Mobile-Phones.aspx

46. That Facebook friend might be 10 years old, and other troubling news Consumer Reports Magazine. 2011 Jun; Retrieved from http://www.consumerreports.org/cro/magazine-archive/2011/june/e lectronics-computers/state-of-the-net/facebook-concerns/index.htm.

47. Heo, J., Oh, J., Subramanian, S. V., Kim, Y., \& Kawachi, I. (2014). Addictive Internet use among Korean adolescents: A national survey. PloS One, 9, 1-8.

48. Christakis DA, Moreno MM, Jelenchick L, Myaing MT, Zhou C Problematic internet usage in US college students: a pilot study. BMC Med. 2011;9:77.

49. Morrison CM, Gore H. The relationship between excessive Internet use and depression: a questionnaire-based study of 1,319 young people and adults. Psychopathology. 2010;43(2):121-6.

50. Black, W.D., Shaw, M. (2008). Internet addiction definition, assessment, epidemiology and clinical management.CNS Drugs, 22(5), 353-365.

51. Park, Min-Hyeon \& Park, E-Jin \& Choi, Jeewook \& Chai, Sukhi \& Lee, Ji-Han \& Lee, Chul \& Kim, Dai-Jin. (2011). Preliminary study of Internet addiction and cognitive function in adolescents based on IQ tests. Psychiatry research. 190. 275-81. 10.1016/j.psychres.2011.08.006.

52. Huang $\mathrm{H}$, Leung L. Instant messaging addiction among teenagers in China: Shyness, alienation, and academic performance decrement CyberPsychology \& Behavior. 2009;12(6):675-679.

53. Jacobsen WC, Forste R. The Wired Generation: Academic and Social Outcomes of Electronic Media Use Among University Students Cyberpsychology, Behavior, and Social Networking. 2011;14(5):275-280.

54. Kirschner PA, Karpinski AC. Facebook and academic performance. Computers in Human Behavior. 2010;26:1237-1245

55. Junco R, Cotten S. No A 4 U: The relationship between multitasking and academic performance. Computers \& Education. 2012;59(2):505-514.

56. Walther JB, Liang Y, DeAndrea DC, Tong ST, Carr CT, Spottswood EL, Amichai-Hamburger Y. The effect of feedback on identity shift in computer mediated communication. Media Psychology. 2011;14:1-26

57. Hofferth SL, Moon UJ. Electronic play, study, communication, and adolescent achievement, 2003-2008. Journal of Research on Adolescents. 2011;22(2):215-224

58. Markstrom CA. Identity formation of American Indian adolescents: local, national, and global considerations. Journal of Research on Adolescence. 2010;21(2):519-535.

59. Muduli, J. R. (2014). Addiction to Technological Gadgets and Its Impact on Health and Lifestyle: A Study on College Students. National Institute of Technology, Rourkela, India.

60. Patton, D. U., Eschmann, R. D., Elsaesser, C., \& Bocanegra, E. (2016) Sticks, stones and Facebook accounts: What violence outreach workers know about social media and urban based gang violence in Chicago. Computers in Human Behavior, 65, 591-600.

61. Dong G, Lu Q, Zhou H, Zhao X Precursor or sequela: pathological 
disorders in people with Internet addiction disorder. PLoS One. 2011;6(2):e14703.

62. Punamaki R, Wallenius M, Nygard C, Saarni L, Rimpela A. Use of information and communication technology (ICT) and perceived health in adolescence: The role of sleeping habits and waking-time tiredness. Journal of Adolescence. 2007;30:569-585.

63. Shah Ruchita, Chauhan Nidhi, Gupta Anoop Krishna, Sen Mahadev Singh (2016): Short communication Adolescent-parent conflict in the age of social media: Case reports from India *, Department of Psychiatry, Postgraduate Institute of Medical Education and Research, Chandigarh 160012, India. Asian Journal of Psychiatry 23 (2016) 24-26.

64. Yen JY, Ko CH, Yen CF, Wu HY, Yang MJ. The comorbid psychiatric symptoms of Internet addiction: attention deficit and hyperactivity disorder (ADHD), depression, social phobia, and hostility. J Adolesc Health. 2007;41(1):93-8.

65. Armum, Puspalathaa and Chellapan, Kalaivani. 2016. Social and emotional self efficacy of adolescents: measured and analyzed interdependencies within and across academic achievement level. International Journal for Adolescents and Youth, vol.21, 279-288.

66. O'Keefee, G. S., Clarke-Pearson, K., \& Council on Communications and Media. (2011). Clinical report - The impact of social media on children, adolescents, and families. Pediatrics, 127, 800-804

67. Grieve R, Indian M, Witteveen K, Tolan GA, Marrington J. Face-to-face or Facebook: Can social connectedness be derived online? Computers in Human Behavior. 2013;29:604-609. http://dx.doi.org/10.1016/j.chb.2012.11.017

68. Jelenchick LA, Eickhoff JC, Moreno MA. "Facebook depression?” Social networking site use and depression in older adolescents. Journal of Adolescent Health. 2013;52:128-130.

69. Krayer A, Ingledew DK, Iphofen R. Social comparison and body image in adolescence: a grounded theory approach. Health Education Research. 2008;23(5):892-903.

70. Haferkamp N, Kramer NC. Social comparison 2.0: Examining the effects of online profiles on social-networking sites. Cyberpsychology, Behavior, and Social Networking. 2011;14(5):309-314.

71. Boyd DM, Ellison NB. Social network sites: Definition, history, and scholarship. Journal of Computer-Mediated Communication. 2008;13:210-230

72. Caprara GV, Gerbino M, Paciello M, Di Giunta L, Pastorelli C Counteracting depression and delinquency in late adolescence. European Psychologist. 2010;15(1):34-38.

73. Griffiths, M. D., Király, O., Pontes, H. M., and Demetrovics, Z. (2015). "An overview of problematic gaming," in Mental Health in the Digital Age: Grave Dangers, Great Promise, eds E. Aboujaoude and V. Starcevic (Oxford: Oxford University Press), 27-45.

74. Ahmet, AKIN., and Murat, İSKENDER. (2011). Internet addiction and depression, anxiety and stress, International Online Journal of Educational Sciences, 3(1). 138-148.

75. H. Khoshakhlagh and S. Faramarzi. (2014). The Relationship of Emotional Intelligence and Mental Disorders with Internet Addiction in Internet Users University Students//Addiction and health Vol 6, No 3.

76. Merwe, P. V. (2014). Adolescence, Internet Use, Social Adjustment and Emotional Intelligence. Mediterranean Journal of Social Sciences. doi:10.5901/mjss.2014.v5n23p2327.

77. Sampasa-Kanyinga, H., \& Lewis, R. F. (2015). Frequent use of social networking sites is associated with poor psychological functioning among children and adolescents. Cyberpsychology, Behavior, and Social Networking, 18, 380-385.

78. Fiovaranti, G., Dettore, D., \& Casale, S. (2012). Adolescent Internet addiction: Testing the association between self-esteem, the perception of Internet attributes, and preference for online social interactions. Cyberpsychology, Behavior and Social Networking, 15, 318-323.

79. Xiuqin, H., Zhang, H., Li, M., Wang, J., Zhang, Y., \& Tao, R. (2010). Mental health, personality, and parental rearing styles of adolescents with Internet addiction disorder. Cyberpsychology, Behavior and Social Networking, 13, 401-406.

80. van den Eijnden, R., Meerkerk, G. J., Vermulst, A. A., Spijkerman, R., \& Engels, R. (2008). Online communication, compulsive Internet use, and psychosocial well-being among adolescents: A longitudinal study. Developmental Psychology, 44, 655-665.

81. Mitchell, S. M., Danielle, R., Guidry, E., \& Cukrowicz, K. C. (2015). The relationship between video game play and the acquired capability for suicide: An examination of differences by category of video game and gender. Cyberpsychology, Behavior, and Social Networking, 18, 757-762.

82. Cavanagh, S. R. (2017, August 06). No, Smartphones are Not Destroying a Generation. Retrieved July 23, 2018, from https://www.psychologytoday.com/us/blog/once-more-feeling/201708/n o-smartphones-are-not-destroying-generation

83. Kanter M, Afifi T, Robbins S. The impact of parents "friending" their young adult child on Facebook on perceptions of parental privacy invasions and parent-child relationship quality. Journal of Communication. 2012;62(5):900-917.

84. Chou HG, Edge N. "They are happier and having better lives than I am": The impact of using Facebook on perceptions of others' lives. Cyberpsychology, Behavior, and Social Networking. 2012;15(2):177-120.

85. van Deursen A. J., Bolle C. L., Hegner S. M., Kommers P. A. (2015). Modeling habitual and addictive smartphone behavior: the role of smartphone usage types, emotional intelligence, social stress, self-regulation, age, and gender. Comput. Hum. Behav. 45 411-420.

86. Oktan V. (2011). The predictive relationship between emotion management skills and Internet addiction. Soc. Behav. Pers. Int. J. 39 1425-1430.

87. Melchers M., Li M., Chen Y., Zhang W., Montag C. (2015). Low empathy is associated with problematic use of the internet: empirical evidence from China and Germany. Asian J. Psychiatry 1756-60. 10.1016/j.ajp.2015.06.019.

88. Vossen, H. G., \& Valkenburg, P. M. (2016). Do social media foster or curtail adolescents' empathy? A longitudinal study. Computers in Human Behavior, 63, 118-124. doi:10.1016/j.chb.2016.05.040.

89. Sanghvi, H., \& Rai, D.U. (2015). Internet Addiction and its relationship with Emotional Intelligence and Perceived Stress experienced by Young Adults.

90. Oskenbay, F., Kalymbetova, E., Tolegenova, A., Kabakova, M., Bakiyeva, S., \& Nugmanova, S. (2015). Addictive Behavior among Adolescents. Procedia - Social and Behavioral Sciences, 171, 406-411. doi:10.1016/j.sbspro.2015.01.140.

91. Gabbiadini, A., Riva, P., Andrighetto, L., Volpato, C., \& Bushman, B. J (2013). Interactive Effect of Moral Disengagement and Violent Video Games on Self-Control, Cheating, and Aggression. Social Psychological and Personality Science, 5(4), 451-458. doi:10.1177/1948550613509286.

92. Lin, J. (2013). Do video games exert stronger effects on aggression than film? The role of media interactivity and identification on the association of violent content and aggressive outcomes. Computers in Human Behavior, 29, 535-543

93. Machmutow, K., Perren, S., Sticca, F., \& Alsaker, F. D. (2012). Peer victimisation and depressive symptoms: Can specific coping strategies buffer the negative impact of cybervictimisation? Emotional and Behavioural Difficulties, 17, 403-420.

94. Girl Scouts Study, Girl Scouts Research Institute. (2010). Who's that Girl? Image and Social Media. Retrieved July 23, 2018, from https://www.girlscouts.org/content/dam/girlscouts-gsusa/forms-and-docu ments/about-girl-scouts/research/gsri_social_media_fact_sheet.pdf

95. Boyar, R., Levine, D., \& Zensius, N. (2011). Tech SexUSA: Youth Sexuality and Reproductive

a. Health in the Digital Age. Retrieved on May 30, 2011 from ISIS website b. http://www.isis-inc.org/ISISpaper techsx usa.pdf.

96. Singh, G. 2010. High internet use is related to low emotional intelligence. Retrieved

http://www.examiner.com/cognitive-science-innational/high-internet-use -is-related-to-low-emotional-intelligence?render=print.

97. Correa, T., Hinsley, A. W., \& De Zuniga, H. D. 2010. Who interacts on the Web? The intersection of users' personality and social media use. Computers in Human Behavior 26(2):247-253.

98. Clifford, S. (2009, February 7). Straight talk on digital harassment for teenagers. The New York Times. Retrieved on May 30, 2011 from

a. http://www.nytimes.com/2009/01/27/technology/27iht-adco.1.1970 5877.html.

99. Ellison N, Steinfield C, Lampe C. The benefits of Facebook 'friends': Exploring the relationship between college students' use of online social networks and social capital. Journal of Computer-Mediated Communication. 2007;12(4):1143-1168.

100. Grieve R, Indian M, Witteveen K, Tolan GA, Marrington J. Face-to-face or Facebook: Can social connectedness be derived online? Computers in Human Behavior http://dx.doi.org/10.1016/j.chb.2012.11.017

101. Reich SM, Subrahmanyam K, Espinoza G. Friending, IMing, and hanging out face-to-face: Overlap in adolescents' online and offline social networks. Developmental Psychology. 2012;48(2):356-368.

102. Kwon, O., Wen Y. (2010), "An empirical study of the factors affecting social network service use", Computers in Human Behavior, vol. 26, pp 254-263.

103. Subrahmanyam K, Reich SM, Waechter N, Espinoza G. Online and offline social networks: Use of social networking sites by emerging adults. Journal of Applied Developmental Psychology. 2008;29:420-433.

104. Quinn S, Oldmeadow JA. Is the igeneration a 'we' generation? Social networking use among 9- to 13-year-olds and belonging. 
British Journal of Developmental Psychology. 2013;31:136-142.

105. Naslund, J. A., Grande, S. W., Aschbrenner, K. A., \& Elwyn, G. (2014). Naturally Occurring Peer Support through Social Media: The Experiences of Individuals with Severe Mental Illness Using YouTube. PLoS ONE, 9(10). doi:10.1371/journal.pone.0110171.

106. Frison E, Subrahmanyam K, Eggermont S. The short-term longitudina and reciprocal relationships between peer victimizationon Facebook and adolescents' well-being. J Youth Adolesc 2016 Sep;45(9):1755-1771.

107. Lenhart, A. (2016, February 01). Teens, Social Media \& Technology Overview 2015 | Pew Research Center. Retrieved July 23, 2018, from http://www.pewinternet.org/2015/04/09/teens-social-media-technology2015/

108. Locke J. The de-voicing of society: Why we don't talk to each other anymore. New York: Simon \& Schuster; 1998.

109. Chak K, Leung L. Shyness and locus of control as predictors of Internet addiction and Internet use. CyberPsychology \& Behavior. 2004;7(5):559-570.

110. McIntosh J, MacDonald F, McKeganey N. Why do children experiment with illegal drugs? The declining role of peer pressure with increasing age. Addiction Research \& Theory. 2006;14(3):275-287.

111. Valkenburg PM, Peter J, Schouten AP. Friend networking sites and their relationship to adolescents' well-being and social self-esteem. Cyberpsychology \& Behavior. 2006;9(5):584-590.

112. Engelberg, E., \& Sjöberg, L. (2004). Internet Use, Social Skills, and Adjustment. CyberPsychology \& Behavior, 7(1), 41-47. doi:10.1089/109493104322820101.

113. Strom, P.S., \& Strom, R.D. (2005). Cyberbullying by Adolescents: A Preliminary Assessment. The Educational Forum, 70, 21-36.

114. Tokunaga, R.S. (2010). Following you from home to school: A critica review and synthesis of research on Cyberbullying victimization. Computers in Human Behavior, 26, 277-287.

115. Krejcie, R. V., \& Morgan, D. W. (1970). Determining Sample Size for Research Activities. Educational and Psychological Measurement, 30(3), 607-610. doi:10.1177/001316447003000308.

116. Young, K. S. (1998). Internet Addiction Test. PsycTESTS Dataset doi: $10.1037 / \mathrm{t} 41898-000$

117. Keser, H., Esgi, N., Kocadag, T., \& Bulu, S. (2013). Validity and Reliability Study of the Internet Addiction Test. Mevlana International Journal of Education, 3(4), 207-222. doi:10.13054/mije.13.51.3.4.

118. Vallat-Azouvi, C., Pradat-Diehl, P., \& Azouvi, P. (2012). The Working Memory Questionnaire: A scale to assess everyday life problems related to deficits of working memory in brain injured patients. Neuropsychological Rehabilitation, 22(4), 634-649. doi:10.1080/09602011.2012.681110.

119. Petrides, K. V. (2009). Psychometric properties of the Trait Emotiona Intelligence Questionnaire. In C. Stough, D. H. Saklofske, and J. D Parker, Advances in the assessment of emotional intelligence. New York: Springer. DOI: 10.1007/978-0-387-88370-0_5.

120. Zampetakis, L. A. (2011). Chapter 11 The Measurement of Trait Emotional Intelligence with TEIQue-SF: An Analysis Based on Unfolding Item Response Theory Models. What Have We Learned? Ten Years On Research on Emotion in Organizations, 289-315. doi:10.1108/s1746-9791(2011)0000007016.

121. Muris, P. (2001). Self-Efficacy Questionnaire for Children. PsycTESTS Dataset. doi:10.1037/t11875-000.

122. Minter, A., \& Pritzker, S. (2015). Measuring Adolescent Social and Academic Self-Efficacy. Research on Social Work Practice, 27(7) 818-826. doi:10.1177/1049731515615677.

123. Stat Trek. (2018, December 15). Retrieved from https://stattrek.com/statistics/random-number-generator.aspx

124. Karacic, S., \& Oreskovic, S. (2017). Internet Addiction Through the Phase of Adolescence: A Questionnaire Study. JMIR Mental Health, 4(2) doi:10.2196/mental.5537

125. Kayastha, B., Gurung, A., \& Chawal, R. (2018). A Descriptive Study to Assess the Level of Internet Addiction among Adolescents: A Case Study of High Schools in Mangalore. Journal of Child and Adolescent Behavior, 06(03). doi:10.4172/2375-4494.1000378

126. Xin, M., Xing, J., Pengfei, W., Houru, L., Mengcheng, W., \& Hong, Z (2018). Online activities, prevalence of Internet addiction and risk factor related to family and school among adolescents in China. Addictive Behaviors Reports, 7, 14-18. doi:10.1016/j.abrep.2017.10.003

127. Rębisz, Sławomir \& Sikora, Ilona. (2016). Internet Addiction in Adolescents. Practice and Theory in Systems of Education. 11. 10.1515/ptse-2016-0019.

128. Kasa, Mark \& Hai Inn, Ho. (2013). Relationship Between Emotiona Intelligence And Students Academic Performance - Role Of Ethnic Factor. 10.13140/RG.2.1.3561.0327.

129. https://www.researchgate.net/publication/282636357 RELATIONSHI P BETWEEN EMOTIONAL INTELLIGENCE AND STUDENTS ACADEMI C PERFORMANCE - ROLE OF ETHNIC FACTOR
130. Nouri, N., Moeini, B., Karimi-Shahanjarini, A., Faradmal, J., Ghaleiha, A., \& Asnaashari, M. (2014). Relationship Between Emotional Intelligence and Communication Skills Among High School Students in Hamadan Based on the Theory of Social Support. Journal of Education and Community Health, 1(3), 38-46. doi:10.20286/jech-010345

131. Sekhri, P., Sandhu, M., \& Sachdev, V. (2017). Emerging Understanding of Emotional Intelligence of Teenagers. International Journal of Clinica Pediatric Dentistry, 10(3), 289-292. doi:10.5005/jp-journals-10005-1452

132. Akram, S., Masome, M., \& Davood, A. (2016). The relationship between emotional intelligence and academic achievement in English language among secondary school students in Tehran. International Journal of Humanities And Cultural Studies. Retrieved from http://www.ijhcs.com/index.php/ijhcs/index

133. Al-Tamimi, E. M., \& Al-Khawaldeh, N. A. (2016). Emotiona Intelligence and Its Relation with the Social Skills and Religious Behaviour of Female Students at Dammam University in the Light of Some Variables. International Education Studies, 9(3), 131 doi:10.5539/ies.v9n3p131

134. Furnham, A. (2016). The Relationship between Cognitive Ability, Emotional Intelligence and Creativity. Psychology, 07(02), 193-197. doi:10.4236/psych.2016.72021

135. Lotfi Kashani F., Vaziria S., \& Lotfi Azimi A. (2012). Relationship between Emotional Intelligence and Educational Achievement. Procedia Social and Behavioral Sciences, 69, 1270-1275. doi:https://doi.org/10.1016/j.sbspro.2012.12.061

136. Matešić K. (2015). The Relationship between Cognitive and Emotional he Relationship between Cognitive and Emotional Intelligence and High School Academic Achievement ntelligence and High School Academic Achie. Intelligence and School Success, Coll. Antropol, 39. Retrieved from https://hrcak.srce.hr/166073.

137. Burnett, S., \& Blakemore, S. (2009). The Development of Adolescent Social Cognition. Annals of the New York Academy of Sciences, 1167(1), 51-56. doi:10.1111/j.1749-6632.2009.04509.x

138. Choudhury, S., Blakemore, S., \& Charman, T. (2006). Social cognitive development during adolescence. Social Cognitive and Affective Neuroscience, 1(3), 165-174. doi:10.1093/scan/ns1024

139. Guimarães S., Lemos I., \& Nunes C. (2011). Social Skills and Academic Achievement of Adolescent Immigrants in School Settings. International Journal of Developmental and Educational Psychology, 1, 115-120. Retrieved

from http://infad.eu/RevistalNFAD/2011/n2/volumen1/INFAD 02012311 5-120.pdf

140. Meijs, N., Cillessen, A. H., Scholte, R. H., Segers, E., \& Spijkerman, R (2008). Social Intelligence and Academic Achievement as Predictors of Adolescent Popularity. Journal of Youth and Adolescence, 39(1), 62-72. doi:10.1007/s10964-008-9373-9

141. Mavroveli, Stella \& V. Petrides, K \& Rieffe, Carolien \& Bakker, Femke. (2007). Trait emotional intelligence, psychological well-being and peer-rated social competence in adolescence. British Journal of Developmental Psychology. 25. $263 \quad$ - 275. 10.1348/026151006X118577.

142. Lopes, Paulo \& Brackett, Marc \& Nezlek, John \& Sellin, Ina \& Salovey, Peter. (2019). Running head: Emotional Intelligence and Social Interaction. Retrieved from https://www.researchgate.net/publication/242752531 Running hea d EMOTIONAL INTELLIGENCE AND SOCIAL INTERACTION

143. Razieh, J., Ali, G., Zaman, A. (2012). The Relationship between Internet Addiction and Anxiety in the Universities Students. Interdisciplinary Journal of Contemporary Research in Business, 4, 1.

144. Argyris V Karapetsas, Apostolos J Fotis, \& Nick C Zygouris. (2012) Adolescents and Internet Addiction: A research study of the occurrence. ENCEPHALOS, 49, 67-72. Retrieved from http://www.encephalos.gr/pdf/49-3-02e.pdf

145. Lawrence A. S., Arul \& , T.Deepa. (2013). Emotional Intelligence And Academic Achievement Of High School Students In Kanyakumar District. International Journal Of Physical And Social Sciences. 3 101-107.

146. Lankashini, M. S., Lakmali, V. G., Lenagala, S. A., Liyanage, A. L., \& Arambepola, C. (2017). Level of emotional intelligence and its association with person-related characteristics among grade 8 students in a suburban setting. Ceylon Journal of Medical Science, 54(1), 27 doi:10.4038/cjms.v54i1.480 